\title{
Effects of Different Regeneration Scenarios and Fertilizer Treatments on Soil Microbial Ecology in Reclaimed Opencast Mining Areas on the Loess Plateau, China
}

\author{
Junjian $\mathrm{Li}^{1,2}$, Yuanming Zheng ${ }^{2}$, Junxia Yan ${ }^{1}$, Hongjian $\mathrm{Li}^{1}$, Xiang Wang ${ }^{3}$, Jizheng $\mathrm{He}^{2 *}$, Guangwei Ding ${ }^{4}$ \\ 1 Institute of Loess Plateau, Shanxi University, Taiyuan Shanxi, China, 2 State Key Laboratory of Urban and Regional Ecology, Research Centre for Eco-environmental \\ Sciences, Chinese Academy of Sciences, Beijing, China, 3 Biology Institute of Shanxi, Taiyuan Shanxi, China, 4 Chemistry Department, Northern State University, Aberdeen, \\ South Dakota, United States of America
}

\begin{abstract}
The soil microbial community in reclaimed mining areas is fundamental to vegetative establishment. However, how this community responds to different regeneration scenarios and fertilizer treatments is poorly understood. This research evaluated plant and soil microbial communities from different regeneration scenarios and different fertilizer treatments. Regeneration scenarios significantly influenced soil bacterial, archaeal, and fungal rDNA abundance. The ratios of fungi to bacteria or archaea were increased with fertilizer application. The diversity of both plants and microbes was lowest in Lotus corniculatus grasslands. Regeneration scenario, fertilizer treatment, and their interaction influenced soil microbial richness, diversity and evenness indices. Labile carbon pool 2 was a significant factor affected plant and microbe communities in July, suggesting that plants and microbes may be competing for nutrients. The higher ratios of positive to negative association were found in soil bacteria and total microbe than in archaea and fungi. Stronger clustering of microbial communities from the same regeneration scenario indicated that the vegetative composition of regeneration site may have a greater influence on soil microbial communities than fertilizer treatment.
\end{abstract}

Citation: Li J, Zheng Y, Yan J, Li H, Wang X, et al. (2013) Effects of Different Regeneration Scenarios and Fertilizer Treatments on Soil Microbial Ecology in Reclaimed Opencast Mining Areas on the Loess Plateau, China. PLoS ONE 8(5): e63275. doi:10.1371/journal.pone.0063275

Editor: Vishal Shah, Dowling College, United States of America

Received September 24, 2012; Accepted April 3, 2013; Published May 2, 2013

Copyright: ( $\odot 2013 \mathrm{Li}$ et al. This is an open-access article distributed under the terms of the Creative Commons Attribution License, which permits unrestricted use, distribution, and reproduction in any medium, provided the original author and source are credited.

Funding: This work was financially supported by the Natural Science Foundation of China (41271530) and the National Science and Technology Program (2012BAC10B04 and 2008BAD95B04). The funders had no role in study design, data collection and analysis, decision to publish, or preparation of the manuscript.

Competing Interests: The authors have declared that no competing interests exist.

*E-mail: jzhe@rcees.ac.cn

\section{Introduction}

The considerable growth of the mining industry in China over the last few decades has generated a vast amount of solid waste, which occupies a huge area of land [1]. In 2006, regulations were initiated to reclaim abandoned coal mining areas for agriculture and forestry in Shanxi Province [1,2]. It would be useful to have indicators to assess the effectiveness of reclamation treatments. Traditionally, the criteria for judging the effectiveness of such treatments largely involve vegetation coverage and diversity, soil erosion and physicochemical characteristics [3]. In contrast, soil microbial ecology is not well understood, and is important for establishment vegetation, soil formation and transformation of nutrients, especially during the initial stages of reclamation $[4,5]$.

The majority on studies of the effects of mine reclamation on microorganisms have focused on specific fungal groups (particularly mycorrhizae) $[6,7]$, and microbial biomass and activity $[5,8-$ 10]. Studies have demonstrated that mycorrhizae can promote plant growth [11], improve soil structure [12] and maintain plant biodiversity and ecosystem stability [13]. Microbial activity has been assessed by measuring enzyme activity or metabolic quotient $[14,15]$. Soil microbial biomass and activity have been found to be lower in reclaimed mining areas compared to undisturbed sites $[3,14]$; and many investigations support the hypothesis that soil microbial biomass and activity increase as reclamation progresses $[3,9,10]$. However, the increasing trend was found in only recently reclaimed areas [15]. In addition, Mummey et al. [4] found that the total bacterial and fungal biomasses showed opposite trends as reclamation progressed.

Recently, genetic profiling methods have produced more information on soil microbial ecology compared to the cultivation of isolated microbes $[16,17]$. The genetic characteristics of the soil microbial community in forest, grassland, and farmland were reported in literature [18-21]. But, few reports focus on soil microbial communities in reclaimed mining areas [5,15]. Bacterial RISA (ribosomal RNA intergenic spacer analysis) fingerprinting has been used to demonstrate the effects of raw parent material properties on the microbial indices of reclaimed mine spoils [5]. Both bacterial and fungal DGGE (denaturing gradient gel electrophoresis) profiles have clearly shown differences between reclaimed and natural sites, but could not discriminate between time since treatment or treatment types [15]. T-RFLP (terminal restriction fragment length polymorphism) analysis is a highly reproducible genetic profiling method that has also been proven to be very useful for describing differences and changes in soil microbial community structures [22-24].

Bacteria, archaea, and eukaryota form the three main domains of the phylogenic tree of life [25]. The diversity and ecological significance of archaea has received rather less attention compared to bacteria and fungi [26]. In this study, we investigated bacterial, archaeal and fungal communities in the initial development stage 
of post-mining rehabilitation in east central Lvliang Mountains, China. We investigated the effects of vegetation type and fertilizer treatment on microbial diversity and composition. We hypothesized that both the vegetation and application of fertilizer would produce significant effects on soil microbial community structure. Fertilizer was only applied once just prior to planting in our study, therefore, we further predict that vegetation type will have a larger impact on microbial properties than fertilizer treatment.

\section{Materials and Methods}

\subsection{Study Sites}

Research was conducted at Antaibao Mine in Northwest Plateau Loess $\left(37^{\circ} 09.4^{\prime} \mathrm{E} ; 111^{\circ} 31.1^{\prime} \mathrm{N}\right)$. The climate is terrestrial temperate, and the area experiences monsoons. Annual average precipitation is 480 to $510 \mathrm{~mm}$, with rainfall occurring mainly in the summer. The annual average air temperature is about $10.1^{\circ} \mathrm{C}$, with the lowest average minimum temperature in January $\left(-5.6^{\circ} \mathrm{C}\right)$ and the highest average maximum temperature in July $\left(23.7^{\circ} \mathrm{C}\right)$. The frost-free season ranges in length from 180 to 200 days. Undisturbed soil in the area is classified as Cumulic Anthrosol (WBR).

Ecological reconstruction was initiated on the abandoned land in 2009, and there were four regeneration scenarios including Lotus corniculatus (CO), Medicago sativa (SA) grasslands, Pinus tabulaeformis plantation (TA), and Salix matsudana -Sabina chinensis mixed forest (MF). The grass seed was sow in rows (row space, $20 \mathrm{~cm}$ ), and the seeding rates of $L$. corniculatus and $M$. sativa were 5 and
$10 \mathrm{~kg} \cdot \mathrm{hm}^{-2}$, respectively. 3-year-old P. tabulaeformis and S. chinensis, and 5-year-old S.matsudana seedling were planted $2 \mathrm{~m}$ apart. There were four fertilizer treatments in total: $\mathrm{CK}=$ no fertilizer added, $\mathrm{IN}=$ inorganic fertilizer $\left(750 \mathrm{~kg} / \mathrm{hm}^{2} ; \mathrm{N}: \mathrm{P}_{2} \mathrm{O}_{5}=18: 12\right)$ added, $\mathrm{OR}=$ organic fertilizer $\left(45 \mathrm{~m}^{3} / \mathrm{hm}^{2} ; \mathrm{N}: 1.7 \%\right.$, Organic matter: $24.1 \%)$ added, and $\mathrm{IO}=$ combination of inorganic and organic fertilizer $\left(375 \mathrm{~kg} / \mathrm{hm}^{2}\right.$ inorganic fertilizer $+22.5 \mathrm{~m}^{3} / \mathrm{hm}^{2}$ organic fertilizer) to soils.

We only investigated plant species in the field; we did not sample plant species. There were no endangered or protected species involed in this study. The location is Antaibao Mine Company that is state-owned enterprise. No specific permits were required for the described field studies.

\subsection{Study Plots Survey and Soil Sampling}

To study the characteristics of the various plant communities under different restoration types, quadrats were set up in the study areas. Quadrats of $20 \mathrm{~m} \times 20 \mathrm{~m}$, and $1 \mathrm{~m} \times 1 \mathrm{~m}$ were established in forest and grassland communities, respectively. There were 3 replications for each of the 16 treatments, resulting in a total of 48 quadrates. Sampling occurred on two occasions, April and July 2011. The cover, height, diameter at breast height (DBH), individual number for each tree species, and the cover and height for herbs were recorded in each quadrat [1).

From each site, 6 soil cores $(7.5 \mathrm{~cm}$ diameter $\times 10 \mathrm{~cm}$ depth) were randomly collected in the middle of rows and mixed from the profile of each plot and bulked [5]. Subsamples for microbial

Table 1. Primers, probes and PCR conditions used for real-time PCR and T-RFLP.

\begin{tabular}{|c|c|c|c|c|c|}
\hline $\begin{array}{l}\text { Target } \\
\text { group }\end{array}$ & Primer and probe & Sequence $\left(5^{\prime}-3^{\prime}\right)$ & Reaction system & Thermal profile & Reference \\
\hline \multicolumn{6}{|c|}{ Real-time PCR } \\
\hline \multirow[t]{3}{*}{ Bacteria } & Primer Bact1369FB & CGGTGAATACGTTCYCGG & $\begin{array}{l}25 \mu \mathrm{l}: 12.5 \mu \mathrm{l} \text { Premix Ex } \operatorname{Taq}^{\mathrm{TM}}, 1 \mu \mathrm{l} \\
\mathrm{BSA}, 0.5 \mu \mathrm{l} \text { each primer and probe, } \\
2 \mu \mathrm{l} \text { template, } 8 \mu \mathrm{l} \mathrm{H}_{2} \mathrm{O}\end{array}$ & $\begin{array}{l}10 \mathrm{~s} \text { at } 95^{\circ} \mathrm{C} \text { for initial denaturation; } \\
35 \text { cycles of } 15 \mathrm{~s} \text { at } 95^{\circ} \mathrm{C}, 1 \mathrm{~min} \text { at } 56^{\circ} \mathrm{C}\end{array}$ & {$[55]$} \\
\hline & Primer Prok1492R & GGWTACCTTGTTACGACTT & & & \\
\hline & Probe TM1389F & CTTGTACACACCGCCCGTC & & & \\
\hline \multirow[t]{2}{*}{ Archaea } & Primer Ar364aF & CGGGGYGCASCAGGCGCGAA & $\begin{array}{l}25 \mu \mathrm{l}: 12.5 \mu \mathrm{l} \text { of } \mathrm{SYBR}^{\circledR} \text { Premix Ex } \\
\text { Taq }^{\mathrm{TM}}, 1 \mu \mathrm{l} \text { BSA, } 0.5 \mu \mathrm{l} \text { each primer, } \\
2 \mu \mathrm{l} \text { template, } 8.5 \mu \mathrm{l} \mathrm{H}_{2} \mathrm{O}\end{array}$ & $\begin{array}{l}30 \mathrm{~s} \text { at } 94^{\circ} \mathrm{C} \text { for initial denaturation; } \\
40 \text { cycles of } 20 \mathrm{~s} \text { at } 94^{\circ} \mathrm{C}, 30 \mathrm{~s} \text { at } 59^{\circ} \mathrm{C} \text {, } \\
\text { and } 30 \mathrm{~s} \text { at } 72^{\circ} \mathrm{C}\end{array}$ & {$[56]$} \\
\hline & Primer Ar934b & GTGCTCCCCCGCCAATTCCT & & & \\
\hline \multirow[t]{2}{*}{ Fungi } & Primer NS1 & GTAGTCATATGCTTGTCC & $\begin{array}{l}25 \mu \mathrm{l}: 12.5 \mu \mathrm{l} \text { of } \mathrm{SYBR}^{\circledR} \text { Premix Ex } \\
\text { Taq }^{\mathrm{TM}}, 1 \mu \mathrm{l} \text { BSA, } 0.5 \mu \mathrm{l} \text { each primer, } \\
2 \mu \mathrm{l} \text { template, } 8.5 \mu \mathrm{l} \mathrm{H}_{2} \mathrm{O}\end{array}$ & $\begin{array}{l}3 \mathrm{~min} \text { at } 95^{\circ} \mathrm{C} \text { for initial denaturation; } \\
40 \text { cycles of } 10 \mathrm{~s} \text { at } 95^{\circ} \mathrm{C}, 30 \mathrm{~s} \text { at } 55^{\circ} \mathrm{C} \text {, } \\
\text { and } 1 \mathrm{~min} \text { at } 72^{\circ} \mathrm{C}\end{array}$ & {$[57]$} \\
\hline & Primer FUNG & CATTCCCCGTTACCCGTTG & & & \\
\hline \multicolumn{6}{|c|}{ PCR for T-RFLP } \\
\hline \multirow[t]{2}{*}{ Bacteria } & Primer 27F-FAM & GAGTTTGATCCTGGCTCAG & $\begin{array}{l}50 \mu \mathrm{l}: 5 \mu \mathrm{l} 10 \times \mathrm{PCR} \text { buffer }\left(\mathrm{MgCl}_{2},\right. \\
2 \mathrm{mM}), 4 \mu \mathrm{l} 2.5 \mathrm{mM} \text { dNTPs, } 0.5 \mu \mathrm{l} \\
\text { EX-Taq polymerase }\left(5 \mathrm{U} \mathrm{I}^{-1}\right), 1 \mu \mathrm{l} \\
\text { each primer, } 1 \mu \mathrm{l} \mathrm{BSA}, 4 \mu \mathrm{l} \text { template, } \\
33.5 \mu \mathrm{l} \mathrm{H}_{2} \mathrm{O} \text { (Reaction system for } \\
\text { bacteria, archaea and fungi) }\end{array}$ & $\begin{array}{l}5 \mathrm{~min} \text { at } 94^{\circ} \mathrm{C} ; 35 \text { cycles of } 45 \mathrm{~s} \text { at } 94^{\circ} \mathrm{C} \text {, } \\
45 \mathrm{~s} \text { at } 54^{\circ} \mathrm{C}, 72^{\circ} \mathrm{C} \text { for } 90 \mathrm{~s} ; 10 \mathrm{~min} \text { at } \\
72^{\circ} \mathrm{C} \text {. }\end{array}$ & {$[58]$} \\
\hline & Primer $1492 R$ & ACGGCTACCTTGTTACGACT & & & \\
\hline \multirow[t]{2}{*}{ Archaea } & Primer Ar364aF & CGGGGYGCASCAGGCGCGAA & & $\begin{array}{l}35 \text { cycles of } 45 \mathrm{~s} \text { at } 94^{\circ} \mathrm{C}, 45 \mathrm{~s} \text { at } 58^{\circ} \mathrm{C}, 60 \mathrm{~s} \\
\text { at } 72^{\circ} \mathrm{C} ; 10 \mathrm{~min} \text { at } 72^{\circ} \mathrm{C} \text {. }\end{array}$ & {$[56]$} \\
\hline & Primer Ar934b-FAM & GTGCTCCCCCGCCAATTCCT & & & \\
\hline \multirow[t]{2}{*}{ Fungi } & Primer NS1-FAM & GTAGTCATATGCTTGTCC & & $\begin{array}{l}5 \mathrm{~min} \text { at } 94^{\circ} \mathrm{C} ; 35 \text { cycles of } 30 \mathrm{~s} \text { at } 94^{\circ} \mathrm{C}, 30 \mathrm{~s} \\
\text { at } 56^{\circ} \mathrm{C}, 60 \mathrm{~s} \text { at } 72^{\circ} \mathrm{C} ; 10 \mathrm{~min} \text { at } 72^{\circ} \mathrm{C} .\end{array}$ & [57] \\
\hline & Primer FUNG & CATTCCCCGTTACCCGTTG & & & \\
\hline
\end{tabular}


Table 2. Soil pH, bulk density, organic carbon, nitrogen, labile carbon pool 1 and 2 (LC1 and LC2), and recalcitrant pool carbon $(\mathrm{RC})$ in the reclaimed mining area in July.

\begin{tabular}{llllllll}
\hline & pH & Bulk density & Organic carbon & Nitrogen & LC1 & LC2 & RC \\
\hline CO-CK & $7.96 \pm 0.01 \mathrm{bA}$ & $1.20 \pm 0.04 \mathrm{aB}$ & $2.61 \pm 0.13 \mathrm{aB}$ & $0.33 \pm 0.01 \mathrm{aA}$ & $1.15 \pm 0.19 \mathrm{aB}$ & $0.36 \pm 0.25 \mathrm{aA}$ & $1.10 \pm 0.09 \mathrm{abAB}$ \\
CO-IN & $7.87 \pm 0.03 \mathrm{aA}$ & $1.23 \pm 0.04 \mathrm{aA}$ & $2.49 \pm 0.23 \mathrm{aAB}$ & $0.37 \pm 0.02 \mathrm{aB}$ & $1.47 \pm 0.24 \mathrm{aB}$ & $0.42 \pm 0.16 \mathrm{aA}$ & $0.60 \pm 0.17 \mathrm{aA}$ \\
CO-IO & $7.92 \pm 0.04 \mathrm{abA}$ & $1.25 \pm 0.02 \mathrm{aA}$ & $2.18 \pm 0.40 \mathrm{aB}$ & $0.34 \pm 0.01 \mathrm{aB}$ & $1.15 \pm 0.18 \mathrm{aB}$ & $0.15 \pm 0.09 \mathrm{aA}$ & $0.88 \pm 0.45 \mathrm{aAB}$ \\
CO-OR & $7.89 \pm 0.02 \mathrm{aA}$ & $1.16 \pm 0.08 \mathrm{aA}$ & $3.22 \pm 0.19 \mathrm{bC}$ & $0.43 \pm 0.02 \mathrm{bB}$ & $1.28 \pm 0.29 \mathrm{aB}$ & $0.47 \pm 0.24 \mathrm{aA}$ & $1.47 \pm 0.30 \mathrm{bA}$ \\
SA-CK & $8.01 \pm 0.06 \mathrm{aA}$ & $1.01 \pm 0.05 \mathrm{aA}$ & $2.29 \pm 0.28 \mathrm{abB}$ & $0.35 \pm 0.01 \mathrm{aA}$ & $0.58 \pm 0.19 \mathrm{aA}$ & $0.44 \pm 0.09 \mathrm{aA}$ & $1.28 \pm 0.31 \mathrm{bB}$ \\
SA-IN & $7.93 \pm 0.04 \mathrm{aAB}$ & $1.14 \pm 0.11 \mathrm{abA}$ & $2.14 \pm 1.06 \mathrm{abAB}$ & $0.29 \pm 0.01 \mathrm{aA}$ & $0.70 \pm 0.10 \mathrm{aA}$ & $0.35 \pm 0.05 \mathrm{aA}$ & $1.69 \pm 0.05 \mathrm{cC}$ \\
SA-IO & $8.05 \pm 0.17 \mathrm{aA}$ & $1.32 \pm 0.09 \mathrm{cA}$ & $1.29 \pm 0.03 \mathrm{aA}$ & $0.25 \pm 0.01 \mathrm{aA}$ & $0.45 \pm 0.06 \mathrm{aA}$ & $0.31 \pm 0.10 \mathrm{aAB}$ & $0.54 \pm 0.05 \mathrm{aA}$ \\
SA-OR & $8.06 \pm 0.28 \mathrm{aA}$ & $1.26 \pm 0.05 \mathrm{bcAB}$ & $2.61 \pm 0.23 \mathrm{bAB}$ & $0.46 \pm 0.04 \mathrm{bB}$ & $0.67 \pm 0.10 \mathrm{aA}$ & $0.49 \pm 0.09 \mathrm{aA}$ & $1.45 \pm 0.24 \mathrm{bcA}$ \\
TA-CK & $7.95 \pm 0.01 \mathrm{bA}$ & $1.35 \pm 0.04 \mathrm{aC}$ & $1.68 \pm 0.23 \mathrm{aA}$ & $0.34 \pm 0.04 \mathrm{aA}$ & $0.69 \pm 0.19 \mathrm{aA}$ & $0.27 \pm 0.09 \mathrm{aA}$ & $0.72 \pm 0.18 \mathrm{aA}$ \\
TA-IN & $7.87 \pm 0.06 \mathrm{aA}$ & $1.27 \pm 0.02 \mathrm{aA}$ & $1.68 \pm 0.13 \mathrm{aA}$ & $0.36 \pm 0.03 \mathrm{aB}$ & $0.50 \pm 0.19 \mathrm{aA}$ & $0.54 \pm 0.16 \mathrm{aA}$ & $0.64 \pm 0.20 \mathrm{aA}$ \\
TA-IO & $7.88 \pm 0.01 \mathrm{aA}$ & $1.33 \pm 0.17 \mathrm{aA}$ & $1.86 \pm 0.08 \mathrm{abB}$ & $0.35 \pm 0.02 \mathrm{aB}$ & $0.70 \pm 0.19 \mathrm{aA}$ & $0.50 \pm 0.18 \mathrm{aB}$ & $0.67 \pm 0.15 \mathrm{aA}$ \\
TA-OR & $7.91 \pm 0.02 \mathrm{abA}$ & $1.34 \pm 0.06 \mathrm{aB}$ & $2.21 \pm 0.27 \mathrm{bA}$ & $0.36 \pm 0.04 \mathrm{aA}$ & $0.77 \pm 0.11 \mathrm{aA}$ & $0.48 \pm 0.09 \mathrm{aA}$ & $0.95 \pm 0.39 \mathrm{bA}$ \\
MF-CK & $8.24 \pm 0.11 \mathrm{bB}$ & $1.17 \pm 0.07 \mathrm{aB}$ & $2.73 \pm 0.34 \mathrm{aB}$ & $0.33 \pm 0.00 \mathrm{aA}$ & $0.72 \pm 0.13 \mathrm{aA}$ & $0.89 \pm 0.16 \mathrm{aB}$ & $1.11 \pm 0.41 \mathrm{aAB}$ \\
MF-IN & $7.97 \pm 0.03 \mathrm{aB}$ & $1.29 \pm 0.18 \mathrm{aA}$ & $3.09 \pm 0.27 \mathrm{abB}$ & $0.52 \pm 0.03 \mathrm{bC}$ & $0.84 \pm 0.15 \mathrm{aA}$ & $1.11 \pm 0.10 \mathrm{aB}$ & $1.14 \pm 0.36 \mathrm{aB}$ \\
MF-IO & $7.91 \pm 0.10 \mathrm{aA}$ & $1.26 \pm 0.06 \mathrm{aA}$ & $3.56 \pm 0.15 \mathrm{bC}$ & $0.36 \pm 0.02 \mathrm{aB}$ & $1.07 \pm 0.11 \mathrm{aB}$ & $1.15 \pm 0.23 \mathrm{aC}$ & $1.34 \pm 0.23 \mathrm{aB}$ \\
MF-OR & $8.03 \pm 0.04 \mathrm{aA}$ & $1.27 \pm 0.08 \mathrm{aAB}$ & $3.10 \pm 0.42 \mathrm{abB}$ & $0.31 \pm 0.02 \mathrm{aA}$ & $0.94 \pm 0.11 \mathrm{aA}$ & $0.95 \pm 0.10 \mathrm{aB}$ & $1.21 \pm 0.44 \mathrm{aA}$ \\
\hline
\end{tabular}

Data are means \pm standard deviations. Treatments with the same lower case letters are not significantly different from one another for the same regeneration scenario $(P>0.05)$. Treatments with the same capital letters are not significantly different from one another for the same fertilizer treatment $(P>0.05)$.

$\mathrm{CO}, \mathrm{SA}, \mathrm{TA}$ and MF respectively represent Lotus corniculatus, Medicago sativa, Pinus tabulaeformis and Salix matsudana-Sabina chinensis mixed forest.

CK, IN, IO and OR respectively represent no, inorganic, organic and a combination of inorganic and organic fertilizer added to soils.

doi:10.1371/journal.pone.0063275.t002

analysis were stored at $4^{\circ} \mathrm{C}$ until DNA extraction ( $<2$ weeks). Subsamples for other analyses were air dried. All soil samples were sieved to pass $2 \mathrm{~mm}$.

\subsection{Soil Chemical Analysis}

Values $\left(\mathrm{g} \mathrm{cm}^{-3}\right)$ for soil bulk density (BD) were obtained using the gravimetric method. Soil $\mathrm{pH}$ in $\mathrm{dH}_{2} \mathrm{O}$ was measured in subsets of field-moist soils at a soil:solution ratio of $1: 5$ (g:ml) after $0.5-1 \mathrm{~h}$. Soil organic carbon (SOC) was determined using the dichromate oxidation method. Total nitrogen $(\mathrm{TN})$ was analyzed by the Kjeldahl method [27]. The labile and recalcitrant carbon pools were quantified by the two-step acid hydrolysis procedure with $\mathrm{HS}_{2} \mathrm{O}_{4}[28,29]$.

\subsection{DNA Extraction}

DNA was extracted from $0.5 \mathrm{~g}$ fresh soil samples using Ultraclean TM soil DNA Isolation Kits (MoBio Laboratory, USA) following the manufacturer's protocol. The extracted DNA was eluted with $5 \mathrm{ml}$ of solution S5 (MoBio Laboratories, cat. no. 12800-100) and stored at $-20^{\circ} \mathrm{C}$. The DNA extracts were 10 -fold diluted and used as template with a final content of 1-10 ng in each reaction mixture to amplify soil bacterial, archaeal, and fungal rRNA genes.

\subsection{PCR Assay for Real-time Quantification and T-RFLP}

Real-time PCR was performed on an iCycler iQ 5 thermocycler (Bio-Rad). The probe TM189F and Premix Ex Taq ${ }^{\mathrm{TM}}$ (Takara Biotechnology, Japan) were applied into bacterial 16S rRNA gene quantitative assay. The reaction mixture for quantifying archaeal and fungal rRNA gene included SYBR ${ }^{\circledR}$ Premix Ex Taq ${ }^{\mathrm{TM}}$ with Green I (Takara Biotechnology, Japan). Primers were labeled at the $5^{\prime}$ end with the reporter dye FAM (6-carboxy-fluorescein) for
T-RFLP analysis. The detailed information on primer, probe, and PGR condition are listed in table 1.

\subsection{T-RFLP Analysis}

All PCR products were verified using $1 \%$ agarose gel electrophoresis and purified with Wizard ${ }^{\circledR}$ SV Gel and PCR Clean-Up System (Promega, USA). Purified products were digested in separate reactions with restriction endonucleases $H h a \mathrm{I}$, HaeIII and MspI (Takara Biotechnology, Japan) and incubated at $37^{\circ} \mathrm{C}$ for $3 \mathrm{~h}$ in the manufacturer's recommended reaction buffer. Digestions were in a total volume of $25 \mu$, including $4 \mathrm{U}$ of enzyme and about $500 \mathrm{ng}$ of DNA. The digestion products were further purified, and a portion was mixed with deionized formamide and the internal standard GeneScan-ROX1000 (bacteria)/LIZ 500 (archaea and fungi) (Applied Biosystems). The mixtures were denatured for $3 \mathrm{~min}$ at $95^{\circ} \mathrm{C}$, and the DNA fragments were size separated using a 3130xl Genetic Analyzer (Applied Biosystems).

\subsection{Statistical Analysis}

The effects of regeneration scenario and fertilizer treatment on plant and soil microbe characteristics were examined with separately one-way analyses of variance (ANOVA). A three-way ANOVA was applied to analyses the effects of season, regeneration scenario and fertilizer treatment on soil microbial communities. Plant species-pairs and microbial RF (Restricted fragment)pairs association were analyzed by Spearman rank correlation. These statistical analyses were performed using SPSS 13.0 for Windows.

Plant species importance values (IV) for each quadrat were calculated using the following formulas [2]: 

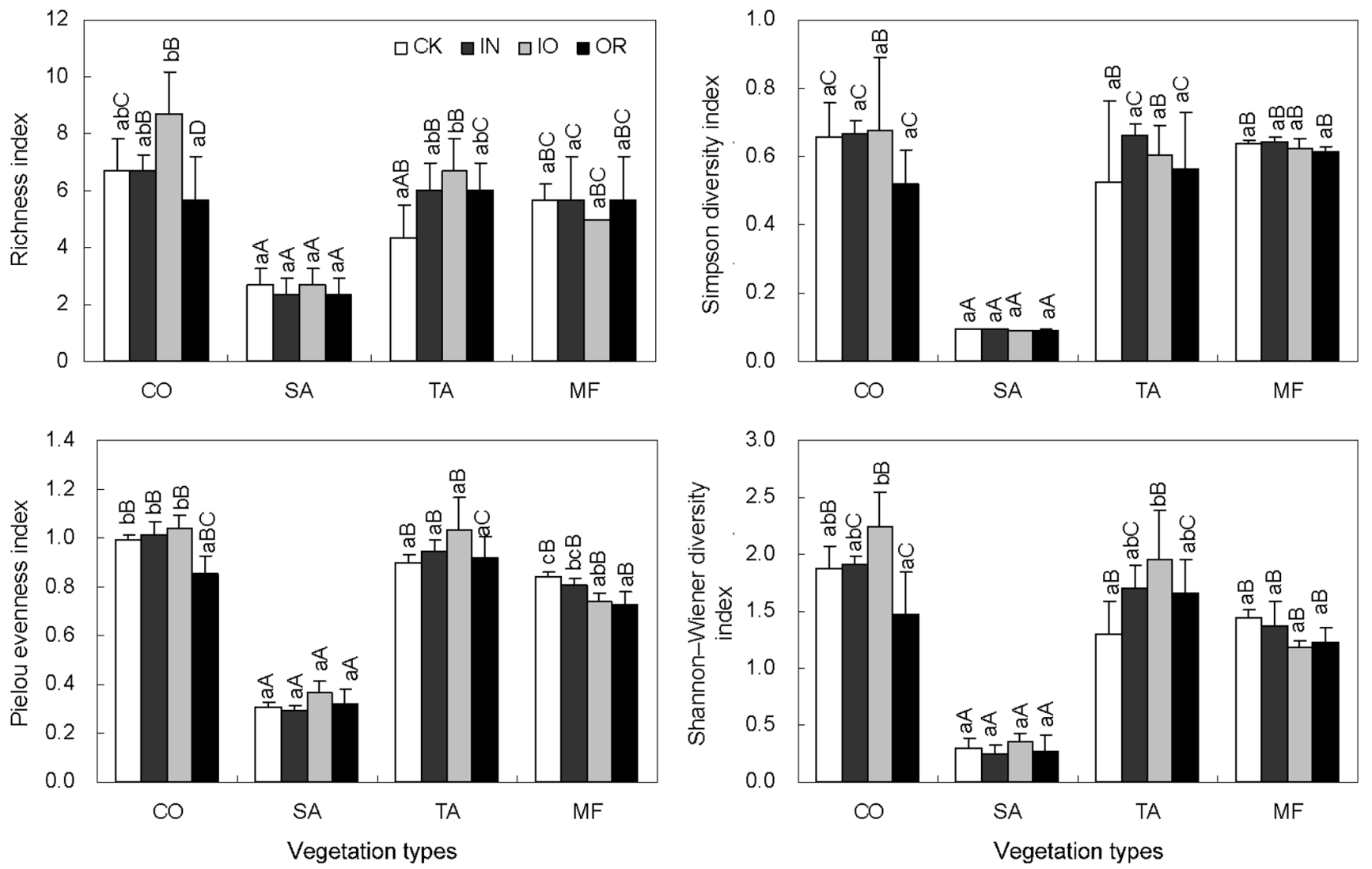

Figure 1. Plant species richness index, Shannon-Wiener diversity index, Simpson diversity index, and Pielou evenness index in the reclaimed mining area. Points show the means of three replicates, and vertical bars show standard deviations. Treatments with the same lower case letters are not significantly different from one another for the same regeneration scenario $(P>0.05)$. Treatments with the same capital letters are not significantly different from one another for the same fertilizer treatment $(\mathrm{P}>0.05)$. CO, SA, TA, and MF represent Lotus corniculatus, Medicago sativa, Pinus tabulaeformis, and Salix matsudana-Sabina chinensis mixed forest. CK, IN, IO, and OR represent no fertilizer, inorganic, organic, and a combination of inorganic and organic fertilizer added to soils.

doi:10.1371/journal.pone.0063275.g001

$$
\begin{aligned}
\mathrm{IV}_{\text {tree }}= & (\text { relative density }+ \text { relative frequency } \\
& + \text { relative dominance }) \div 3
\end{aligned}
$$

$\mathrm{IV}_{\text {shrub and herb }}=($ relative coverage + relative height $) \div 2$

$$
\begin{aligned}
& \mathrm{IV}_{\text {plant community }}= \\
& \quad\left(5 \times \mathrm{IV}_{\text {tree }}+2.5 \times \mathrm{IV}_{\text {shrub }}+2.5 \times \mathrm{IV}_{\text {grass }}\right) \div 10
\end{aligned}
$$

To reveal their variation among different restoration types, plant species, and RF richness, diversity and evenness in each quadrat were determined. Four species diversity indices were employed:
(a) Species number as the richness index $(S)$
(b) Shannon-Wiener diversity index:

$$
H^{\prime}=-\sum P_{i} \ln P_{i}
$$

(c) Simpson diversity index:

$$
D=1-\sum P_{i}^{2}
$$

(d) Pielou evenness index:

$$
E=\mathrm{H}^{\prime} / \ln S
$$

$S$ is the number of plant species. $P_{i}$ is the relative importance value of plant species i. $P i=\mathrm{IV} i / \mathrm{IV} ; \mathrm{IV}_{\mathrm{i}}$ and $\mathrm{IV}$ are the importance value of species $i$ and all plant species in a quadrate, respectively [2]. For soil microbial community, $S$ is the number of $\mathrm{RF}$ and $P_{i}$ is the relative ratio of $\mathrm{RF}$ i [30].

A matrix of IVs for plant and matrices of RFs ratios for bacteria, archaea, fungi and total microbes were used as the basis of the community analysis. According to quantification PCR, the ratios of logarithm of the bacterial, archaeal and fungal rRNA gene copies approximate to $4: 3: 3$. Matrix (totalmicrobe $)=\left(4 \times \operatorname{ratio}_{(\mathrm{RF}-\text { Bacteria })}\right.$ $\left.+3 \times \operatorname{ratio}_{(\text {RF-Archaea })}+3 \times \operatorname{ratio}_{(\mathrm{RFs}-\mathrm{Fungi})}\right) \div 10$. A matrix of environmental values was also established, which were used to analyze the relationships between samples and environmental factors using canonical correspondence analysis (CCA). These calculations were 

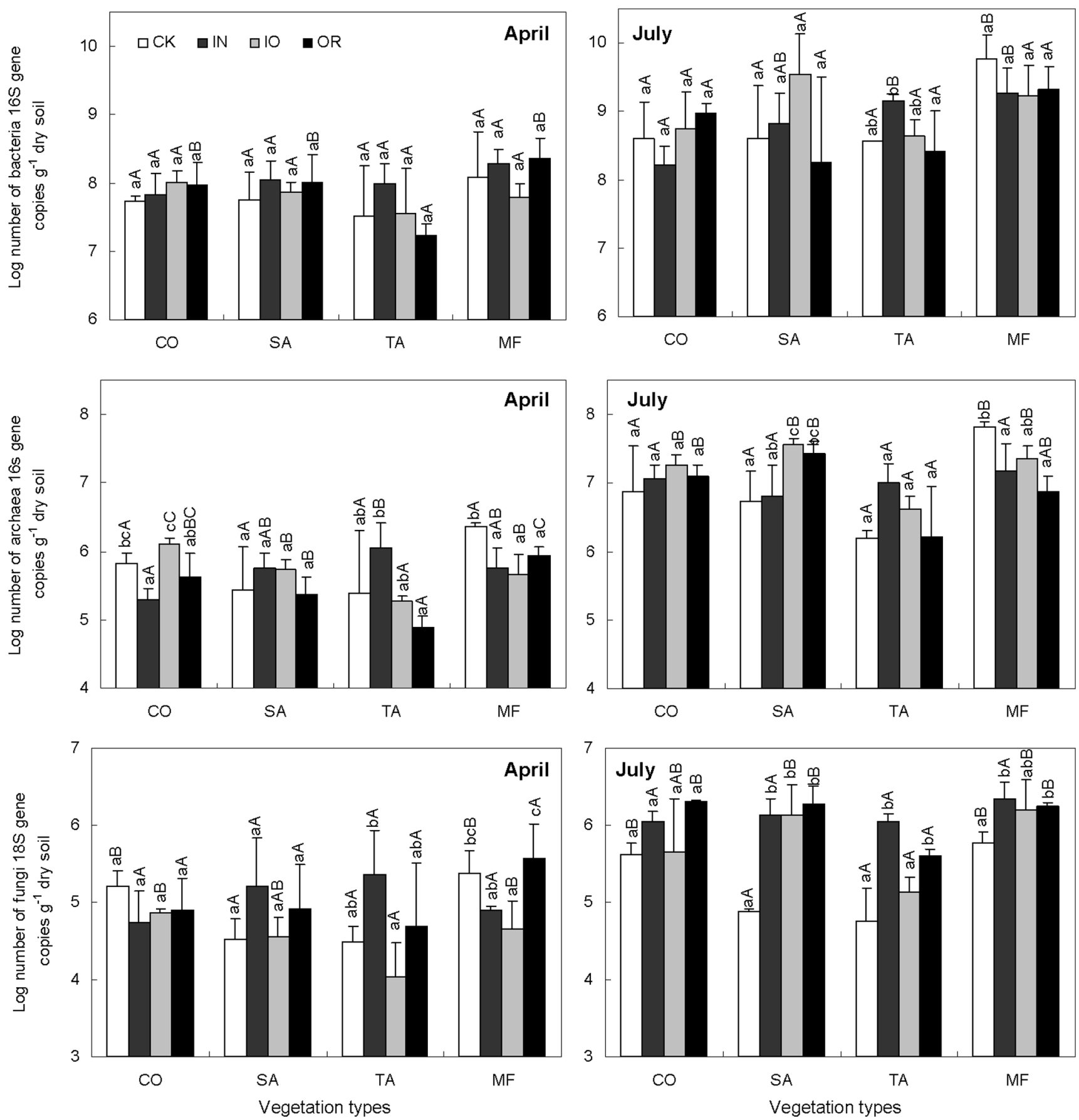

Figure 2. Abundance of soil bacteria, archaea, and fungi rRNA genes in the reclaimed mining area. Points show the means of three replicates, and vertical bars show standard deviations. Treatments with the same lower case letters are not significantly different from one another for the same regeneration scenario $(P>0.05)$. Treatments with the same capital letters are not significantly different from one another for the same fertilizer treatment $(\mathrm{P}>0.05)$. CO, SA, TA, and MF represent Lotus corniculatus, Medicago sativa, Pinus tabulaeformis, and Salix matsudana-Sabina chinensis mixed forest. CK, IN, IO, and OR represent no fertilizer, inorganic, organic, and a combination of inorganic and organic fertilizer added to soils.

doi:10.1371/journal.pone.0063275.g002

carried out using the CANOCO 4.5 [31], and the plant and microbial data were logarithmic transformed for the analysis. The significance level $(\mathrm{P}<0.05)$ between species and environmental data was used the Monte Carlo permutation test (Number of permutation is 499), and the significant environmental factors were applied into final CGA.

\section{Results}

\subsection{Soil Chemical Properties}

Fertilizer treatments had significant effects $(\mathrm{P}<0.05)$ on soil $\mathrm{pH}$ in all vegetation types except SA grassland (Table 2). Soil pH in mixed forest was higher than in other regeneration scenarios under both CK and IN treatments. However, no significant 
Table 3. Results of three-way ANOVA showing the effects of season, regeneration scenarios and fertilizer treatments for soil bacteria, archaea, fungi and total microbes RFs richness index $(S)$, Shannon-Wiener diversity index $\left(H^{\prime}\right)$, Simpson diversity index $(D)$ and Pielou evenness index $(E)$.

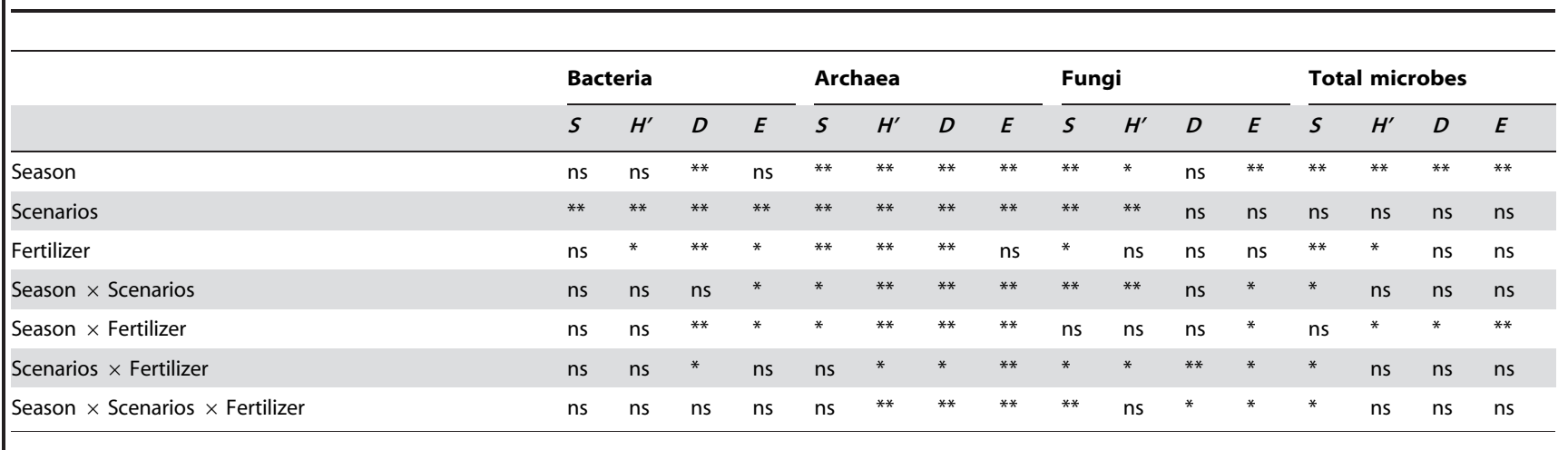

**Effect is significant at the 0.01 level;

*Effect is significant at the 0.05 level. ns, effect is not significant.

doi:10.1371/journal.pone.0063275.t003

differences $(\mathrm{P}>0.05)$ were found between scenarios treated with IO or OR fertilizer. Fertilizer treatments significantly $(\mathrm{P}<0.05)$ increased soil organic carbon in SA grassland and less significant effects of fertilizer treatments on soil organic carbon were demonstrated in other regeneration scenarios. In most cases, there were significantly $(\mathrm{P}<0.05)$ higher levels of soil organic carbon in $\mathrm{CO}$ and $\mathrm{MF}$ sites with the same fertilizer treatment. OR fertilizer significantly improved soil nitrogen content in the two grasslands and only inorganic fertilizer affected soil nitrogen in the

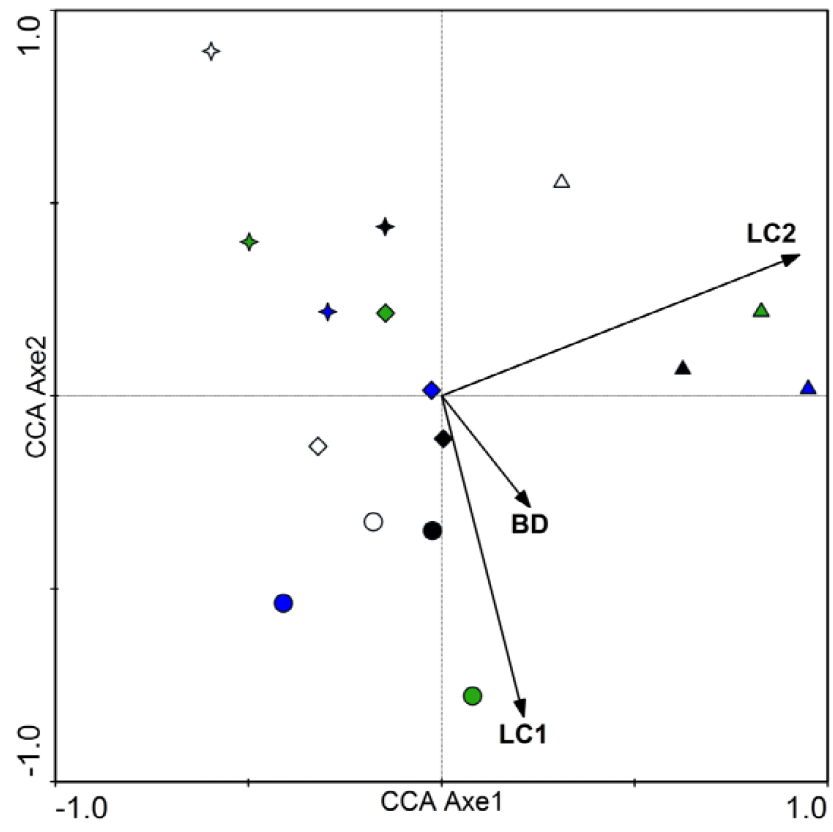

Figure 3. CCA ordination biplot of 16 quadrats and environmental factors for plant communities in the reclaimed mining area. Arrows indicate the direction and magnitude of measurable variables associated with plant community structures. Circle, Star, Diamond and Up-triangle symbol types respectively represent Lotus corniculatus, Medicago sativa, Pinus tabulaeformis and Salix matsudanaSabina chinensis mixed forest. White, green, blue and black respectively represent no, inorganic, organic and a combination of inorganic and organic fertilizer added to soils. BD, LC1, and LC2 are bulk density, soil labile pool carbon 1 and 2, respectively.

doi:10.1371/journal.pone.0063275.g003 mixed forests, but there were no significant differences among fertilizer treatments in the TA plantation. No significant differences in soil nitrogen were found between regeneration scenarios that did not have any fertilizer treatment. Under IN and IO fertilizer treatments, soil nitrogen from SA grassland was significantly $(\mathrm{P}<0.05)$ lower than that of the other vegetation types. Fertilizer did not produce significant effects $(\mathrm{P}<0.05)$ on labile carbon pools 1 and 2 (LC1 and LC2). Under the same fertilizer treatment, a significantly higher LC1 was found in CO grassland, and a significantly higher LC2 was found in MF. Different regeneration scenarios and fertilizer treatments both significantly $(\mathrm{P}<0.05)$ influenced soil recalcitrant carbon levels.

\subsection{Plant Community Composition and Diversity}

Plant community composition and the coverage of vegetation were investigated (Table S1). The vegetation coverage was lower in $\mathrm{CO}$ grassland than the other regeneration scenarios. IO fertilizer treatments significantly $(\mathrm{P}<0.05)$ improved the plant species richness and Shannon-Wiener diversity in $\mathrm{CO}$ and TA sites, but no significant effects were found in other regeneration scenarios (Figure 1). There were no significant $(\mathrm{P}>0.05)$ differences in the Simpson diversity index among fertilizer treatments. With the exception of SA grassland, fertilizer significantly $(\mathrm{P}<0.05)$ influenced the Pielou evenness index, although the effect was not consistent. Plant diversity indices from SA grassland were significantly lower than other sites treated with the same fertilizer.

\subsection{Soil Bacterial, Archaeal, and Fungal Abundance}

The seasonal effects on the abundance of soil microbial rRNA genes were significant (Figure 2). Fertilizer treatments produced no significant effects on soil bacterial 16S rRNA gene copy number, with the exception of the TA plantation in July. Either, there were no pronounced effects of fertilizer treatments on soil archaeal and fungal rRNA gene abundance in most cases. Different regeneration scenarios had a more obvious influence on the microbial rRNA gene abundance than fertilizer treatments, especially in archaea. In addition, the differences were more visible between regeneration scenarios in July than in April. In July, the log ratios of bacteria: fungi and archaea: fungi under $\mathrm{SA}$ and $\mathrm{MF}$ were lower with fertilizer treatments (Figure $\mathrm{Sl}$ ), which indicated that fertilizers show more positive effects on the growth of fungi than bacteria and archaea. 

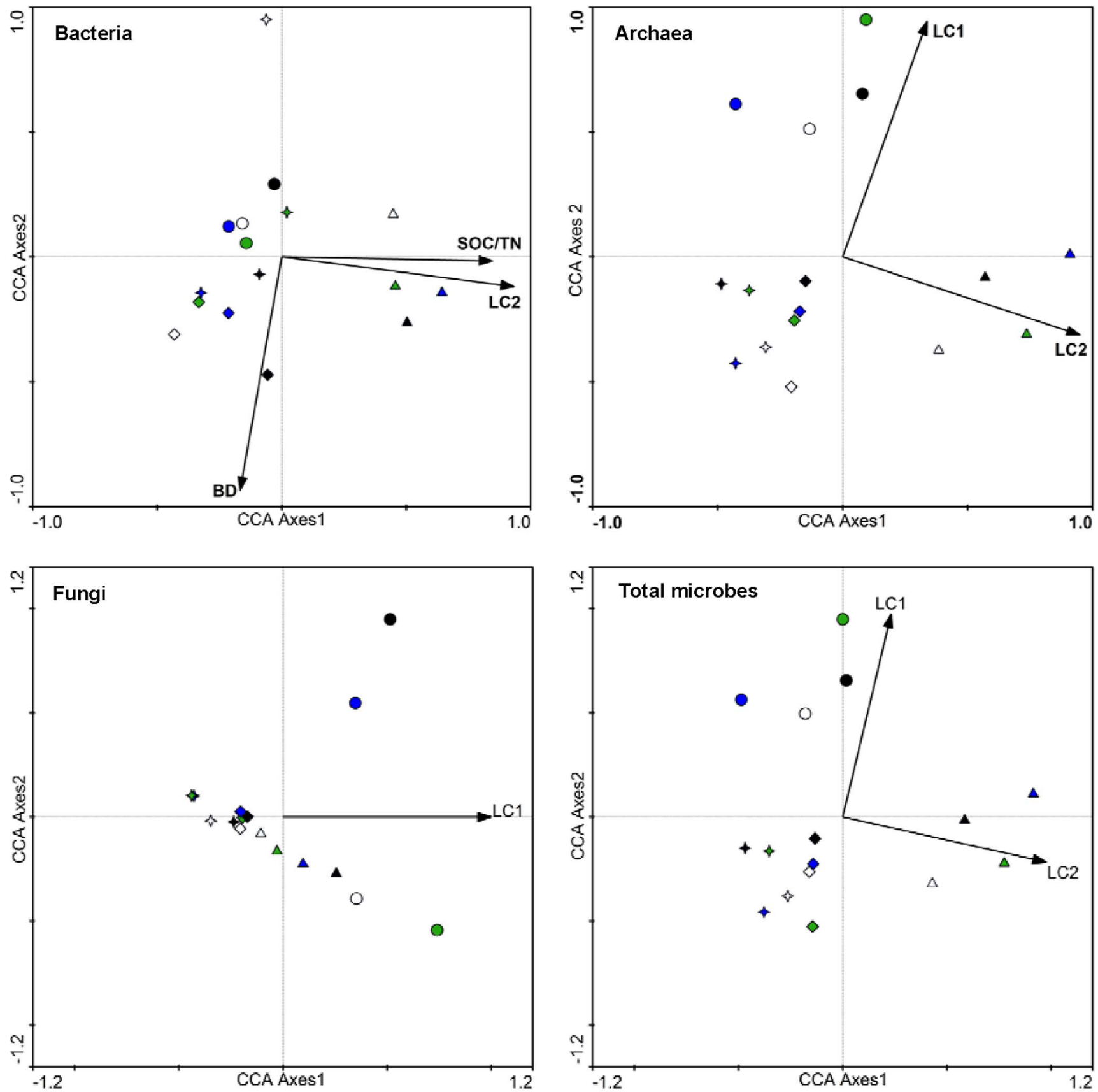

Figure 4. CCA ordination biplot of 16 quadrats and environmental factors for soil bacterial, archaeal, fungal, and total microbial communities in the reclaimed mining area in July. Arrows indicate the direction and magnitude of measurable variables associated with soil microbial communities structures. Circle, Star, Diamond and Up-triangle symbol types respectively represent Lotus corniculatus, Medicago sativa, Pinus tabulaeformis and Salix matsudana-Sabina chinensis mixed forest. White, green, blue and black respectively represent no, inorganic, organic and a combination of inorganic and organic fertilizer added to soils. BD, SOC/TN, LC1, and LC2 are the soil bulk density, ratio of soil organic carbon to total nitrogen, labile carbon pool 1 and 2, respectively.

doi:10.1371/journal.pone.0063275.g004

\subsection{Soil Microbial T-RFLP Profiles and Diversity}

T-RFLP profiles of soil bacterial, archaeal, and fungal rRNA genes from study sites were produced using the endonuclease enzymes HhaI, HaeIII and MspI. The effects of sampling date, regeneration scenarios, and fertilizer treatments on microbial diversity indices produced by $H h a \mathrm{I}$ are listed in Table 3 .

When soil bacteria 16S rRNA genes were restricted using HhaI, the 77 bp RF had the highest relative abundance and there were
RFs unique to each regeneration scenario. In T-RFLP profiles of soil archaeal $16 \mathrm{~S}$ rRNA restricted using $H h a \mathrm{I}$, the 320 bp RF had the highest relative abundance at all sites. Fragments of 136 and $141 \mathrm{bp}$ were found in regeneration areas where trees grew, but not in grasslands; and the fragments lower than $88 \mathrm{bp}$ were only observed in fertilizer treatments. Both regeneration scenario and fertilizer treatment demonstrated an influence on T-RFLP profiles of soil fungi 18S rRNA restricted using HhaI enzyme (Figure S2). 
Soil bacterial and total microbial diversity indices inferred from fragments restricted using $H h a \mathrm{I}$ and $M s p \mathrm{I}$ were more liable to be influenced by sampling date, regeneration scenarios, fertilizer treatments and their interaction, than those restricted using HaeIII(Table 3 and Table S2). Soil archaeal diversity indices from RFs produced using $H h a \mathrm{I}$ appeared to be more sensitive to these factors. Most of the diversity indices for fungal fragments restricted using $M s p \mathrm{I}$ were not significantly influenced by vegetation type or fertilizer treatment. Sampling date was the most significant factor affecting microbial diversity, and followed by regeneration scenario, then fertilizer treatment. The Pielou evenness index $(E)$ and richness index $(S)$ were the most and least susceptible for these factors, respectively.

\subsection{Spearman Rank Correlation Test for Inter-species Correlation}

Plant species-pair and microbial inter-RF ratios of positive and negative association of the Spearman rank correlation test are listed in Table S3. Plant species-pair ratios at the CO and TA sites were higher than in the other two treatments. Fertilizer treatments improved both plant and microbe ratios. Soil microbe inter-RFs ratios differed with regeneration scenarios. Inter-RF ratios of total soil microbes were the highest, and decreased in order from bacteria to fungi to archaea.

\subsection{Effect of Environmental Factors on Plant and Soil Microbial Community Composition and Species Distribution}

The results of CCA showed that the eigenvalues of axes 1 and 2 was respectively $62.3 \%$ and $44.0 \%$, and the first two axes explained $64.7 \%$ of species-environment relations (i.e. Plantenvironmental data). Liable carbon pool and bulk density were significantly linked to the plant community variability $(\mathrm{P}<0.05)$, and positively correlated with the first axes (Figure 3).

The relationships between environmental factors and soil microbial communities, according to T-RFLP profiles restricted using HhaI, were shown by the CCA method (Figure S3, Figure 4). In April, the significant environmental factors that affected bacterial, archaeal, fungal, and total microbial communities were $\mathrm{pH}$, ratio of soil organic carbon to nitrogen, bulk density and LC2 (Figure S3). Soil pH was positively correlated with the first axes in bacterial and total microbial communities; however, negative effects were shown in fugal communities. Bulk density was significant environmental factors for archaeal and fungal communities, and positively correlated with the second axes. In July, LC1 was positively correlated with the first two axes, but the contrary correlations were demonstrated between LC2 and the first two axes (Figure 4). Treatments from the same regeneration scenario tended to cluster together more than those from the same fertilization treatment. Similar results were found when CGA was applied to test relationships between environmental factors and microbial RFs restricted using HaeIII and MspI enzymes (results not shown).

\section{Discussion}

The growth of $L$. corniculatus demands high fertility soil, and we observed that fertilizer significantly improved plant coverage in $\mathrm{CO}$ grasslands. $M$. sativa has been widely planted in reclamation sites in the Loess Plateau due to its strong resistance to drought and barren soil [32]. In our study, $M$. sativa grew well, the coverage being over $90 \%$ with the available space almost used; other species, therefore, could not easily invade and plant richness, diversity and evenness was significantly lower in these grasslands
(Figure 1). Possibly, due to the lower coverage in CO grasslands, plant diversity was higher as invasive species was able to establish easily. Inter-plant spacing provided gaps for shrub growth so plant diversity was also higher in TA and MF plantations.

A higher growth rate of vegetation results in more soil nutrients being consumed. Meanwhile, litter and dead roots are not degraded during the initial reclamation period. We observed higher coverage and above-ground biomass in SA than $\mathrm{CO}$ grasslands, and levels of soil organic carbon, total nitrogen, and labile carbon pool were lower in SA than CO grasslands (Table 2). Declining trends have been recorded in soil organic carbon, nitrogen, and microbial biomass in fast-growing poplar and Eucalyptus plantations [33-35].

In July, the different regeneration scenarios in our study demonstrated more obvious influences on soil microbial rDNA copy numbers (Figure 2). In addition, soil microbial RF richness and diversity were lowest in the SA grasslands where the richness and diversity of above-ground vegetation were also the lowest compared to other regeneration scenarios (Figurel). These results imply that these microbial communities are closely related to plant colonization. Previous studies have also supported the hypothesis that vegetation produces significant effects on the structuring of microbial communities during the pioneer stage of ecosystem development $[36,37]$. The relationship between microbial reproduction and plant colonization involves competition for nutrients primarily during short-term rehabilitation programs [38]. However, nutritive symbiosis was chiefly for long-term rehabilitation potentially between regeneration scenarios and soil microbial communities via the chemical composition, quantities and botanical forms of different plant residues $[39,40]$.

In this study, fertilizer treatments were beneficial for vegetation establishment, particularly in the CO grasslands. Organic fertilizer produced significant $(\mathrm{P}<0.05)$ increases in soil organic and recalcitrant carbon levels and nitrogen content (Table 2). Fertilizers provide different substrates for soil microbial communities [41-43]. There were no significant differences between the three domains of soil microbial rDNA copy numbers (Figure 2). These results differ from previous studies where significant increases in soil microbial biomass due to fertilizer have been reported during the reclamation of barren soils or agricultural fields [44-46]. The difference may be explained by the fact that only a single application of fertilizer was in our study, whereas long-term application of fertilizers was used in other studies.

Soil $\mathrm{pH}$ was significantly $(\mathrm{P}<0.05)$ decreased as a result of fertilizer treatments, especially in the mixed forest (Table 2). However, the application rate of fertilizer used here did not produce significant detrimental effects on plant or microbial growth. Significant plant growth in part may have contributed to a decrease in $\mathrm{pH}$ via litter inputs, organic exudation, and proton extrusion [29,47]. The much lower $\mathrm{pH}$ from sites treated with fertilizer could also be explained by the influence of fertilizer on microbial community structure, e.g., lower $\mathrm{pH}$ levels may improve the competitive advantage of soil fungi that are more suited to weak acid conditions compared to bacteria and archaea. Lower ratios of bacteria and archaea to fungi were found, which was consistent with other studies [48]. In addition, soil $\mathrm{pH}$ influenced soil bacterial and fungal composition across samples $[37,49]$ and was a significant environmental factor in determining soil bacterial and total microbial community composition in April (Figure S3).

Using a Monte Carlo permutation test in CCA, we showed that LC2 was a significant environmental factor affecting both plant and microbial communities in July. However, labile carbon was not the only significant environmental factor that affected soil microbial communities in April (Figure S3). The test also 
supported the view that there may be competition for nutrition between plants and microbes to meet their growth demands in infertile soil. In reclaimed coal mine soils, the development of microbial communities was shown to be stimulated by the presence of an easily available carbon source [9]. Previous studies have also shown that soluble carbon is a dominant influence on microbial communities in other conditions [50-52].

In our study, soil microbial diversity was more affected by the vegetative composition of the regeneration sites than by fertilizer treatments (Table 3). We also found microbial communities stronger clustering from similar regeneration scenarios than form similar fertilizer treatments (Figure 4, S3). These results suggest that regeneration scenarios have greater impacts on the microbial communities than fertilizer treatments. This is probably related to root exudates. In reclaimed post-mining sites near Sokolov (Czech Republic) and near Cottbus, Šourková et al. [14] reported that vegetation type played a more important role in the soil microbial community than substrate, which was mainly dependent on litter quality. We hypothesized that the degradation of litter would not be the primary substrate for soil microbial communities in 3-yearold reclaimed sites.

Higher ratios of positive to negative association from the Spearman rank correlation test indicate that biological community is more steady [53]. The low ratios listed in table $\mathrm{S} 3$ suggested that plant and soil microbe were still in the initial succession period. The higher ratios of bacteria suggested that bacteria would promote the succession of plant, archaea, and fungi, and play an important role in maintaining ecological stability. Our results are similar to Susyan et al. [54]. They reported that soil fungi clearly dominated the microbial communities later in the succession on abandoned arable soils, which suggested that the soil bacterial community prevailed during the initial period.

\section{Conclusions}

The results partly confirmed our hypothesis that soil microbial communities were significantly influenced by regeneration scenarios, however, fertilizer treatments produced less significant influence on soil microbial communities. Regeneration scenarios produced a significant effect on soil microbial rDNA copy numbers and microbial communities. Season showed pronounced effects on soil microbial growth and composition. There may be nutrient competition between vegetation and microbes for their growth during initial rehabilitation period, but mutual benefits would be demonstrated between vegetation and soil microbe with succession progressed in reclaimed mining areas of Shanxi, China.

\section{Supporting Information}

Figure S1 Ratios of soil bacterial, archaeal and fungal log numbers of rRNA gene copy number in the reclaimed mining area. Points show the means of three replicates, and vertical bars show standard deviations. Lower case letters indicate that the means are not significantly different among fertilizer treatments for the same regeneration scenario $(P<0.05)$. Capital letters indicate that the means are not significantly different among regeneration scenarios for the same fertilizer treatment $(P<0.05)$. CO, SA, TA and MF respectively represent Lotus corniculatus, Medicago sativa, Pinus tabulaeformis and Salix matsudana-Sabina chinensis mixed forest. CK, IN, IO and OR respectively represent no, inorganic, organic and a combination of inorganic and organic fertilizer added to soils. (TIF)
Figure S2 Relative fluorescence of soil bacteria, archaea and fungi populations measured by T-RFLP electropherogram target on rRNA gene sequences digested using HhaI restriction enzymes in the reclaimed mining area. $\mathrm{CO}, \mathrm{SA}, \mathrm{TA}$ and $\mathrm{MF}$ respectively represent Lotus corniculatus, Medicago sativa, Pinus tabulaeformis and Salix matsudana-Sabina chinensis mixed forest. CK, IN, IO and OR respectively represent no, inorganic, organic and a combination of inorganic and organic fertilizer added to soils.

(TIF)

Figure S3 GCA ordination biplot of 16 quadrats and environmental factors for soil bacterial, archaeal, fungal, and total microbial communities in the reclaimed mining area in April. Arrows indicate the direction and magnitude of measurable variables associated with soil microbial communities structures. Circle, Star, Diamond and Up-triangle symbol types respectively represent Lotus corniculatus, Medicago sativa, Pinus tabulaeformis and Salix matsudana-Sabina chinensis mixed forest. White, green, blue and black respectively represent no, inorganic, organic and a combination of inorganic and organic fertilizer added to soils. BD, SOC/TN, and LC2 are the soil bulk density, ratio of soil organic carbon to total nitrogen, and labile carbon pool 2, respectively.

(TIF)

Table S1 Plant community composition and coverage in reclaimed mining area. $\mathrm{CO}, \mathrm{SA}, \mathrm{TA}$ and $\mathrm{MF}$ are respectively Lotus corniculatus, Medicago sativa, Pinus tabulaeformis and Salix matsudana -Sabina chinensis mixed forest. CK, IN, IO and OR are respectively no, inorganic, organic and combination of inorganic and organic fertilizer added to soils

(DOC)

Table S2 Results of three-way ANOVA showing the effects of season, regeneration scenarios and fertilizer treatments for Soil bacteria, archaea, fungi and total microbe RFs richness index $(S)$, Shanon-Wiener diversity index $\left(H^{\prime}\right)$, Simpson diversity index $(D)$ and Pielou evenness index $(\boldsymbol{E})$. ** Effect is significant at the 0.01 level; * Effect is significant at the 0.05 level. ns Effect is not significant. (DOC)

Table S3 Ratios of positive and negative association from Spearman rank correlation test of the inter-species correlation of plant and inter-RFs correlation of soil bacteria, archaea, fungi and total microbes in the reclaimed mining area. $\mathrm{CO}, \mathrm{SA}$, TA and $\mathrm{MF}$ represent Lotus corniculatus, Medicago sativa, Pinus tabulaeformis and Salix matsudanaSabina chinensis mixed forest. CK, IN, IO and OR represent no, inorganic, organic and a combination of inorganic and organic fertilizer added to soils.

(DOC)

\section{Acknowledgments}

We are grateful to Professor J. Hughes for constructive comments and linguistic corrections. We thank Dr. L. Jiao for providing help in vegetation investigation.

\section{Author Contributions}

Conceived and designed the experiments: JL HL JH. Performed the experiments: JL JY. Analyzed the data: JL YZ. Contributed reagents/ materials/analysis tools: XW YZ JH. Wrote the paper: JL JH GD. 


\section{References}

1. Zhang J (2005) Succession analysis of plant communities in abandoned croplands in the Eastern Loess Plateau of China. J Arid Environ 63: 458-474.

2. Zhang J, Dong Y (2010) Factors affecting species diversity of plant communities and the restoration process in the loess area of China. Ecol Eng 36: 345-350.

3. Mummey DL, Stahl PD, Buyer JS (2002) Soil microbiological properties 20 years after surface mine reclamation spatial analysis of reclaimed and undisturbed sites. Soil Biol Biochem 34: 1717-1725.

4. Mummey DL, Stahl PD, Buyer JS (2002) Microbial biomass as an indicator of ecosystem recovery following surface mine reclamation. Appl Soil Ecol 21: 251259.

5. Machulla G, Bruns MA, Scow KM (2005) Microbial properties of mine spoil materials in the initial stages of soil development. Soil Sci Soc Am J 69: 10691077.

6. Chen B, Zhu Y, Duan J, Xiao X, Smith SE (2007) Effects of the arbuscular mycorrhizal fungus Glomus mosseae on growth and metal uptake by four plant species in copper mine tailings. Environ Pollut $147: 374-380$.

7. Wang L, Zhang W, Guo G, Qian K, Huang X (2009) Selection experiments for the optimum combination of AMF-plant-substrate for the restoration of coal mines. Mining Sci Tech 19: 479-482.

8. Long J, Huang C, Teng Y, Yao HY (2003) Preliminary study on soil microbes and soil biochemical activities in mining wasteland. Acta Ecol Sin 23: 496-503.

9. Rumpel C, Kögel-Knabner I (2004) Microbial use of lignite compared to recent plant litter as substrates in reclaimed coal mine soils. Soil Biol Biochem 36: 6775.

10. Baldrian P, Trög J, Frouz J, Šnajdr J, Valášková V, et?al. (2008) Enzyme activities and microbial biomass in topsoil layer during spontaneous succession in spoil heaps after brown coal mining. Soil Biol Biochem 40: 2107-2116.

11. Chen B, Roos P, Zhu Y, Jakobsen I (2008) Arbuscular mycorrhizas contribute to phytostabilization of uranium in uranium mining tailings. J Environ Radioactiv 99: 801-810.

12. Rillig MC, Steinberg PD (2002) Glomalin production by an arbuscular mycorrhizal fungus a mechanism of habitat modification? Soil Biol Biochem 34: $1371-1374$.

13. Koide RT, Dickie IA (2002) Effects of mycorrhizal fungi on plant populations. Plant Soil 244 307-317.

14. Šourková M, Frouz J, Fettweis U, Bens O, Hüttl RF, et?al. (2005) Soil development and properties of microbial biomass succession in reclaimed post mining sites near Sokolov (Czech Republic) and near Cottbus (Germany). Geoderma 129: 73-80.

15. Dimitriu PA, Prescott CE, Quideau SA, Grayston SJ (2010) Impact of reclamation of surface-mined boreal forest soils on microbial community composition and function. Soil Biol Biochem 42: 2289-2297.

16. Griffiths RI, Whiteley AS, O'Donnell AG, Bailey MJ (2000) Rapid Method for Coextraction of DNA and RNA from Natural Environments for Analysis of Ribosomal DNA- and rRNA-Based Microbial Community Composition. Appl Environ Microbiol 66: 5488-5491.

17. Nemergut DR, Anderson SSP, Cleveland CC, Martin AP, Miller AE, et?al. (2007) Microbial community succession in an unvegetated recently deglaciated soil. Microbiol Ecol 53: 110-122.

18. Lukow T, Dunceld PF, Liesack W (2000) Use of the T-RFLP technique to assess spatial and temporal changes in the bacterial community structure within an agricultural soil planted with transgenic and non-transgenic potato plants. FEMS Microbiol Ecol 32: 241-247.

19. Johnson MJ, Lee KY, Scow KM (2003) DNA fingerprinting reveals links among agricultural crops soil properties and the composition of soil microbial communities. Geoderma 114: 279-303.

20. Frey B, Stemmer M, Widmer F, Luster J, Sperisen C (2006) Microbial activity and community structure of a soil after heavy metal contamination in a model forest ecosystem. Soil Biol Biochem 38: 1745-1756.

21. Singh BK, Munro S, Potts JM, Millard P (2007) Influence of grass species and soil type on rhizosphere microbial community structure in grassland soils. Appl Soil Ecol 36: 147-165.

22. Leybo AI, Netrusov A, Conrad R (2006) Effect of hydrogen concentration on the community structure of hydrogenotrophic methanogens studied by T-RFLP analysis of 16S rRNA gene amplicons. Microbiol 75 683-688.

23. Bennett LT, Kasel S, Tibbits J (2008) Non-parametric multivariate comparisons of soil fungal composition Sensitivity to thresholds and indications of structural redundancy in T-RFLP data. Soil Biol Biochem 40: 1601-1611.

24. McMahon SK, Wallenstein MD, Schimel JP (2011) A cross-seasonal comparison of active and total bacterial community composition in Arctic tundra soil using bromodeoxyuridine labeling. Soil Biol Biochem 43: 287-295.

25. Woese CR, Fox GE (1977) Phylogenetic structure of the prokaryotic domain the primary kingdoms. PNAS 74: 5088-5090.

26. Woese CR, Kandler O, Wheelis ML (1990) Towards a natural system of organisms Proposal for the domains Archaea Bacteria and Eucarya. PNAS 87: 4576-4579.

27. Lu R (2000) Soil Agrochemical Analysis Method. Beijing, China Agricultural Science Technology Press.

28. Rovira P, Vallejo VR (2002) Labile and recalcitrant pools of carbon and nitrogen in organic matter decomposing at different depths in soil an acid hydrolysis approach. Geoderma 107: 109-141.
29. Li J, Li H, Zhou X, Zhao X, Yan J (2011) Labile and recalcitrant organic matter and microbial communities in soil after conversion of abandoned lands in the Loess Plateau China. Soil Sci 176: 313-325.

30. Ge Y, He J, Zhu Y, Zhang J, Xu Z, et?al. (2008) Differences in soil bacterial diversity driven by contemporary disturbances or historical contingencies? ISME 2: $254-264$.

31. ter Braak CJF, Šmilauer P (2002) CANOCO Reference Manual and CanoDraw for Windows User's Guide Software for Canonical Community Ordination (version 4 5). Microcomputer Power (Ithaca NY USA) 500 p.

32. Li FM, Xu JZ, Sun GJ (2003) Restoration of degraded ecosystems and development of water-harvesting ecological agriculture in the semi-arid Loess Plateau of China. Acta Ecol Sin 23: 1901-1909.

33. Behera N, Sahani U (2003) Soil microbial biomass and activity in response to Eucalyptus plantation and natural regeneration on tropical soil. Forest Ecol Manage 174: 1-11.

34. Ashagrie Y, Zech W, Guggenberger G (2005) Transformation of a Podocarpus falcatus dominated natural forest into a monoculture Eucalyptus globulus plantation at Munesa Ethiopia soil organic $\mathrm{C} \mathrm{N}$ and $\mathrm{S}$ dynamics in primary particle and aggregate-size fractions. Agr Ecosyst Environ 106: 89-98.

35. Zhang X, LiJ, Shi F (2008) Organic carbon and nitrogen contents and microbial biomass in soils under rapid-growth Polar plantation. J Ecol Rural Environ 24: 32-35.

36. Tscherko D, Hammesfahr U, Zeltner G, Kandeler E, Böcker R (2005) Plant succession and rhizosphere microbial communities in a recently deglaciated alpine terrain. Basic Appl Ecol 6: 367-383.

37. Knelman JE, Legg TM, O’Neill SP, Washenberger CL, González A, et?al. (2012) Bacterial community structure and function change in association with colonizer plants during early primary succession in a glacier forefield. Soil Biol Biochem 46: 172-180.

38. Lipson DA, Monson RK (1998) Plant-microbe competition for soil amino acids in the alpine tundra effects of freeze-thaw and dry-rewet events. Oecologia 113: 406-414.

39. Fang M, Motavalli PP, Kremer RJ, Nelson KA (2007) Assessing changes in soil microbial communities and carbon mineralization in Bt and non-Bt corn residue-amended soils. Appl Soil Ecol 37: 150-160.

40. Shi F, Li J, Wang S (2008) Soil organic carbon nitrogen and microbial properties in contrasting forest ecosystems of Northeast China under different regeneration scenarios. Acta Agr Scan B Soil Plant Sci 58: 1-10.

41. Marschne P, Kandeler E, Marschner B (2003) Structure and function of the soil microbial community in a long-term fertilizer experiment. Soil Biol Biochem 35 : 453-461.

42. Zhang Q, Wang G, Yao H (2007) Phospholipid fatty acid patterns of microbial communities in paddy soil under different fertilizer treatments. J Environ Sci 19: 55-59.

43. Li J, Zhao B, Li X, Jiang R, Bing SH (2008) Effects of long-term combined application of organic and mineral fertilizers on microbial biomass soil enzyme activities and soil fertility. Agr Sci China 7: 336-343.

44. Cai X (2002) Effect of different methods of application on degenerated soil I middle part of Tibet. J Soil Water Conserv 16: 12-17.

45. Li J, Zhao B, Li X, Jiang R, Bing SH (2008) Changes of soil microbial properties affected by different long-term fertilization regimes. J Plant Ecol 32: 891-899.

46. Liang B, Yang X, He X, Zhou J (2011) Effects of 17-year fertilization on soil microbial biomass $\mathrm{C}$ and $\mathrm{N}$ and soluble organic $\mathrm{C}$ and $\mathrm{N}$ in Loessial Soil during maize growth. Biol Fertil Soils 47: 121-128.

47. Menyailo OV, Hungate BA, Zech W (2002) The effect of single tree species on soil microbial activities related to $\mathrm{G}$ and $\mathrm{N}$ cycling in the Siberian artificial afforestation experiment. Plant Soil 242: 183-196.

48. Eskelinen A, Stark S, Männistö M (2009) Links between plant community composition soil organic matter quality and microbial communities in contrasting tundra habitats. Oecologia 161: 113-123.

49. Lauber CL, Hamady M, Knight R, Fierer N (2009) Pyrosequencing-based assessment of soil $\mathrm{pH}$ as a predictor of soil bacterial community structure at the continental scale. Appl Environ Microbiol 75 : 5111-5120.

50. Hu SJ, Van Bruggen AHC, Grünwald NJ (1999) Dynamics of bacterial populations in relation to carbon availability in a residueamended soil. Appl Soil Ecol 13: 21-30.

51. Edwards IP, Bürgmann H, Miniaci C, Zeyer J (2006) Variation in microbial community composition and culturability in the rhizosphere of Leucanthemopsis alpina (L.) Heywood and adjacent bare soil along an alpine chronosequence. Microb Ecol 52: 679-692.

52. McCrackin ML, Harms TK, Grimm NB, Hall SJ, Kaye JP (2008) Responses of soil microorganisms to resource availability in urban desert soils. Biogeochem 87: $143-165$.

53. Zhou XY, Wang BS, Li MG, Zan QJ (2000) An analysis of interspecific associations in secondary succession forest communities in Heishiding Nature Reserve, Guangdong Province. Acta Phytoecologica Sinica 24: 332-339.

54. Susyan EA, Wirth S, Ananyeva ND, Stolnikova EV (2011) Forest succession on abandoned arable soils in European Russia - impacts on microbial biomass fungal-bacterial ratio and basal $\mathrm{CO}_{2}$ respiration activity. Eur J Soil Biol 47: 169174 . 
55. Suzuki MT, Taylor LT, Delong EF (2000) Quantitative analysis of small-subunit rRNA genes in mixed microbial populations via 50-nuclease assays. Appl Environ Microbiol 66 : 4605-4614.

56. Schellenberger S, Kolb S, Drake HL (2010) Metabolic responses of novel cellulolytic and saccharolytic agricultural soil bacteria to oxygen. Environ Microbiol 12: 845-861.
57. May LA, Smiley B, Schmidt MG (2001) Comparative denaturing gradient gel electrophoresis analysis of fungal communities associated with whole plant corn silage. Can J Microbiol 47: 829-841.

58. Baker GC, Smith JJ, Cowan DA (2003) Review and re-analysis of domainspecific 16S primers J Microbiol Meth 55: 541-555. 